\title{
Model Matematis Laju Pengeringan Manisan Pepaya dengan Menggunakan Alat Pengering Tipe Rak
}

\author{
Mathematical Model of Papaya Candied Drying Rate Prediction \\ Using Tray Dryer System \\ Murad*, Sukmawaty, Joko Sumarsono, Syahroni Hidayat \\ Program Studi Teknik Pertanian, Fakultas Teknologi Pangan dan Agroindustri, Universitas Mataram, Indonesia \\ *E-mail: muradfatepa@unram.ac.id
}

Diterima: 10 Februari 2021; Disetujui: 9 Agustus 2021

\begin{abstract}
ABSTRAK
Pepaya adalah tumbuhan yang banyak manfaat. Beberapa bagian pohonnya dapat dijadikan obat tradisional, adapun buahnya mengandung nutrisi yang sangat baik bagi kesehatan. Akan tetapi, buah pepaya cepat rusak. Oleh karena itu pengolahan pepaya menjadi bahan pangan lain seperti manisan dapat menjadi alternatif. Untuk membuat manisan pepaya lebih baik menggunakan alat pengering mekanis menggunakan tambahan panas dan memerlukan energi untuk memanaskan bahan dan menguapkan air yaitu dengan menggunakan alat pengering seperti alat pengering tipe rak. Penelitian merupakan penelitian eksperimental yang difokuskan pada penentuan konstanta laju pengeringan manisan pepaya baik hasil eksperimen ataupun prediksi menggunakan pengering tipe rak yang diberikan blower. Variabel yang digunakan adalah kecepatan aliran udara blower 3,43 m/detik dan 4,55 m/detik. Diperoleh hasil bahwa konstanta laju pengeringan prediksi memiliki nilai determinasi $R^{2}$ mencapai lebih dari $90 \%$ dengan nilai RMSE sangat kecil, masing-masing 0,065 dan 0,125. Berdasarkan nilai $R^{2}$ dan RMSE, penggunaan kecepatan aliran udara yang berbeda tidak terlalu mempengaruhi nilai konstanta laju pengeringan.
\end{abstract}

Kata kunci: konstanta laju pengeringan; manisan; pepaya; pengering tipe rak

\section{ABSTRACT}

Papaya is a plant that has many benefits. Some parts of the tree can be used as traditional medicine, while the fruit contains nutrients that are very good for health. However, papaya fruit spoils quickly. Therefore, processing papaya into other food ingredients such as sweets can be an alternative. To make papaya sweets it's better to use a mechanical dryer that uses additional heat and requires energy to heat the ingredients and evaporate the water, namely by using a dryer such as a rack-type dryer. This research is an experimental study that focused on determining the constant drying rate of papaya sweets, both experimental and predictive results using a rack type dryer provided with a blower. The variables used are the blower airflow velocity of $3,43 \mathrm{~m} / \mathrm{s}$ and $4,55 \mathrm{~m} / \mathrm{s}$. The results show that the predictive drying rate constant has a determinant value $R^{2}$ of more than $90 \%$ with a very small $R M S E$ value, 0,065 and 0,125 , respectively. Based on its $R^{2}$ and RMSE value, the use of different air flow rates does not really affect the drying rate constant value.

Keywords: drying rate constant; papaya; sweets; tray dryer

\section{PENDAHULUAN}

Buah Pepaya (Carica papaya L.) termasuk dalam kelompok buah kecil family Caricaceae yang dibudidaya baik pada negara-negara di dunia dengan daerah tropis maupun subtropis (Attri, Dhiman, Sharma, \& Kaushal, 2016). Pepaya adalah tanaman asli Amerika tropis dan diperkenalkan ke India pada abad ke-16 (Yogiraj, Goyal, Chauhan, Goyal, \& Vyas, 2014).

Pepaya memiliki banyak manfaat, daunnya secara tradisional telah banyak digunakan untuk pengobatan berbagai macam penyakit seperti malaria, demam berdarah, penyakit kuning, imunomodulator dan aktivitas antivirus (Yogiraj et al., 2014). Sedangkan buahnya bermanfaat sebagai sumber nutrisi, serat, dan enzim proteolitik yang baik (Kannaujiya, Bunkar, Rai, \& Singh, 2018). Manfaat dari buah pepaya ini mendasari pengolahan pepaya menjadi berbagai jenis makanan dan minuman yang peminatnya berasal dari pasar luar negeri (Purba, 2008). Pepaya memiliki kualitas yang jelas dengan nilai gizi, obat, organoleptik, ekonomi dan tradisional yang tinggi. Ini tersedia dalam jumlah banyak selama musim tertentu tetapi semuanya belum dimanfaatkan sampai batas yang diinginkan (Kannaujiya et al., 2018).

Pemanfaatan yang kurang maksimal disebabkan oleh sifat buahnya yang mudah rusak. Jumlah kerusakan dapat meningkat oleh diantaranya penanganan saat panen yang kurang hati-hati, proses pengemasan, dan proses transportasi (Kannaujiya et al., 2018). Untuk dapat mengurangi tingkat kerusakan buah pepaya, maka pengolahan buah menjadi olahan makanan lain dapat menjadi solusi. Pengawetan buah pepaya merupakan bidang studi yang dibutuhkan untuk menambah nilai, meningkatkan umur simpan, dan meningkatkan aksesibilitas buah. Untuk menjaga manfaat kesehatan dari buah yang sangat mudah busuk ini, dapat diterapkan metode pengeringan (Kannaujiya et al., 2018; Ummah, Purwanto, \& Suryani, 2016).

Pengeringan adalah proses untuk mengurangi aktivitas mikroorganisme perusak pangan dengan cara mengurangi jumlah kadar air hingga mencapai kadar tertentu. Proses pengeringan termasuk pengawetan secara fisik (Khan, 
Rahman, \& Karim, 2020). Proses pengeringan umumnya menggunakan sinar matahari dan dapat juga memanfaatkan mesin pengering. Masyarakat tradisional melakukan proses pengeringan dengan memanfaatkan sinar matahari karena dapat menekan biaya. Akan tetapi metode ini memiliki kelemahan karena sangat tergantung pada cuaca dan tidak optimal jika diterapkan untuk mengeringkan buah-buahan karena dapat mempengaruhi mutu produk. Sehingga mesin pengering menjadi solusi karena dapat memberikan hasil yang lebih baik dan prosesnya juga dapat dikontrol. (Shomali \& Abbasi Souraki, 2019).

Oleh karena itu, pada penelitian ini digunakan mesin pengering untuk membuat manisan pepaya. Mesin pengering yang digunakan bertipe rak yang merupakan alat pengering mekanis dengan tambahan panas dan memerlukan energi untuk memanaskan bahan dan menguapkan air (Ummah et al., 2016). Tambahan panas dialirkan dengan bantuan blower dengan variasi kecepatan udara. Dari penerapan mesin pengering tipe rak dengan variasi kecepatan udara ini akan ditentukan laju pengeringan manisan pepaya baik dari hasil eksperimen ataupun prediksi.

\section{METODOLOGI}

Penelitian ini merupakan penelitian eksperimental dengan analisis pemodelan matematis menggunakan aplikasi Ms. Excel dan SPSS versi 25. Penelitian ini dilakukan di Laboratorium Teknik Bioproses dan Laboratorium Daya dan Mesin Pertanian Pertanian Fakultas Teknologi Pangan dan Agroindustri Universitas Mataram. Bahan penelitian yang digunakan ditampilkan pada Tabel 1. Sedangkan untuk alat pengering digunakan yang bertipe rak yang dirancang-bangun secara mandiri. Gambaran umum alat pengering tipe rak seperti ditunjukkan pada Gambar 1.

Tabel 1. Bahan penelitian

\begin{tabular}{clc}
\hline No & \multicolumn{1}{c}{ Nama Bahan } & Berat (gram) \\
\hline 1 & Pepaya setengah matang & 1500 \\
2 & Gula pasir & 750 \\
3 & Kapur Sirih & 9 \\
\hline
\end{tabular}

Alat pengering berbentuk rak (Tray Dryer), mempunyai bentuk persegi dan di dalamnya berisi rak-rak, yang digunakan sebagai tempat bahan yang akan dikeringkan. Bahan diletakkan di atas rak (tray) yang terbuat dari logam dengan alas yang berlubang-lubang. Kegunaan dari lubang-lubang ini untuk mengalirkan udara panas dan uap air. Luas rak yang digunakan bermacam-macam. Luas rak dan besar lubang-lubang rak tergantung pada bahan yang akan dikeringkan. Apabila bahan yang akan dikeringkan berupa butiran halus, maka lubangnya berukuran kecil. Selain alat pemanas udara, biasanya digunakan juga kipas (fan) untuk mengatur sirkulasi udara dalam alat pengering. Udara setelah melewati kipas masuk ke dalam alat pemanas, pada alat ini udara dipanaskan lebih dahulu kemudian dialirkan di antara rak-rak yang sudah berisi bahan (Taufiq, 2004).

Parameter yang diamati untuk dapat memprediksi laju pengeringan pada proses pengeringan manisan pepaya menggunakan alat pengering tipe rak, adalah Temperature/Suhu $\left({ }^{\circ} \mathrm{C}\right)$, Kelembaban Relatif (\%), Kadar Air (\%), Laju Aliran Udara (m/detik) dan Konstanta Laju Pengeringan (k). Pengukuran suhu dan kelembaban menggunakan termodigital, laju aliran udara dengan anemometer, dan kadar air diukur secara manual dengan pengambilan sampel pada tiap waktu pengamatan menggunakan timbangan digital.

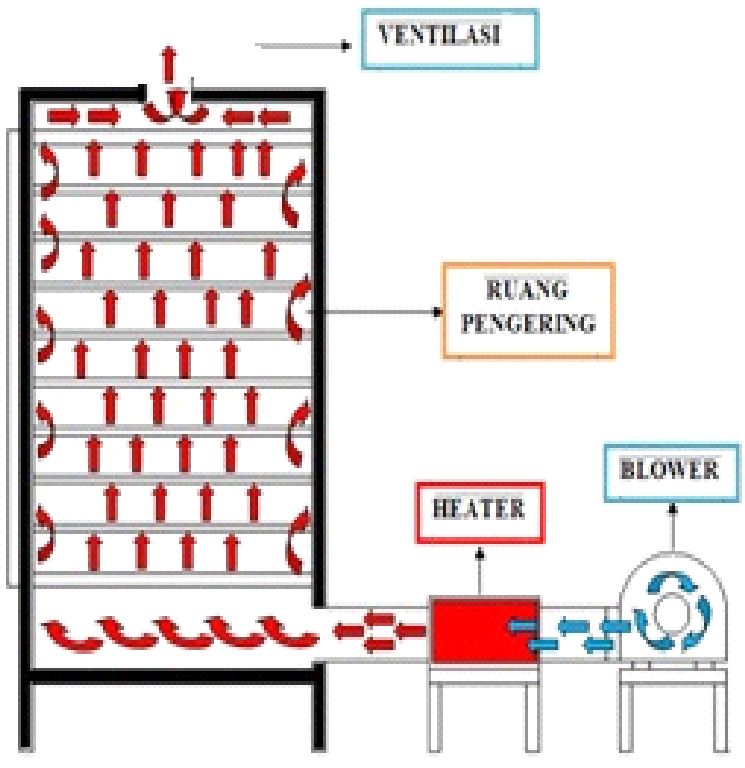

Gambar 1. Alat pengering tipe rak

Proses pengambilan data dilakukan mengikuti flowchart pada Gambar 2. Variabel kecepatan udara blower yang digunakan, ditentukan ada 2, yaitu $3.43 \mathrm{~m} /$ detik dan 4,55 $\mathrm{m} /$ detik. Penentuan nilai kecepatan udara berdasarkan penelitian tentang pengeringan buah apel dengan kecepatan udara maksimal $1.5 \mathrm{~m} /$ detik (Vega-Gálvez et al., 2012). Adapun dari hasil penelitian lain disimpulkan bahwa dengan kecepatan aliran udara yang tinggi dapat mempercepat proses pengeringan buah dan sayur dalam box kecil (Zhang \& Long, 2017). Oleh karena itu dipilih nilai kecepatan aliran udara pada penelitian ini mencapai lebih dari 2 dan 3 kali lipatnya. Kadar air awal bahan berbedabeda untuk setiap kecepatan aliran udara. Pada kecepatan aliran udara $3,43 \mathrm{~m} /$ detik dan $4,55 \mathrm{~m} /$ detik berturut-turut yaitu 90,42 \% dan 94,00 \%. Sedangkan untuk kadar air akhir yang dituju adalah sekitar $\leq 24,00 \%$.

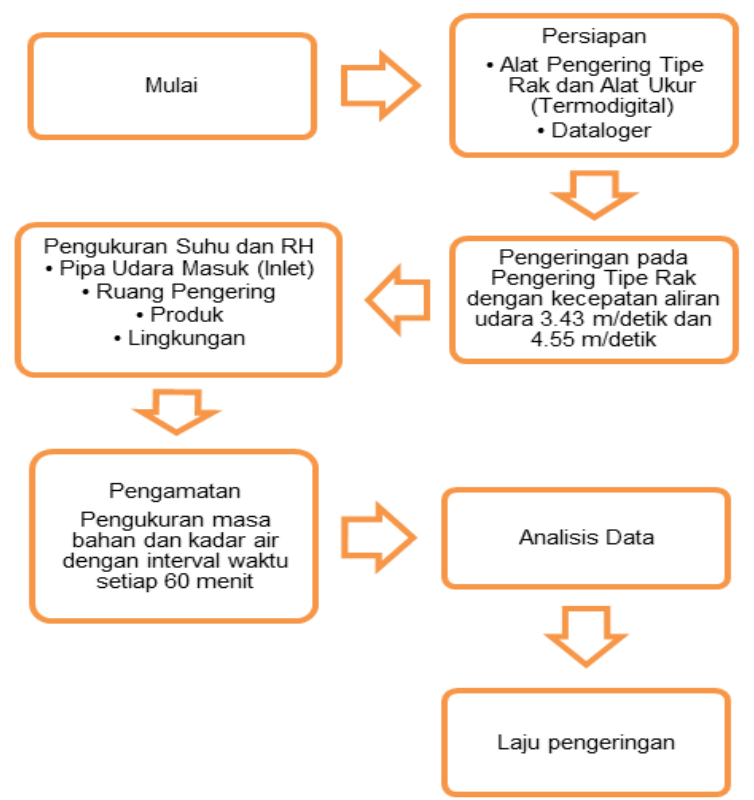

Gambar 2. Diagram alir penelitian pengeringan manisan pepaya 
Pada proses pengeringan kemudian diamati masa bahan dan kadar air setiap 1 jam (60 menit) selama total lama pengeringan 7 jam (420 menit). Selanjutnya dilakukan analisis data untuk memperoleh konstanta laju pengeringan dengan model matematis menggunakan program Ms. Excel dan SPSS versi 25. Konstanta laju pengeringan dapat ditentukan dengan banyak cara. Paling umum dan sederhana sering digunakan persamaan (1) berikut ini (Onwude, Hashim, Janius, Nawi, \& Abdan, 2016):

$\frac{d M}{d t}=-k\left(M-M_{e}\right)$

dari persamaan (1) ini diperoleh persamaan perpindahan massa yang dinyatakan sebagai (El-Beltagy, Gamea, \& Essa, 2007):

$\frac{M-M_{e}}{M_{o}-M_{e}}=e^{-k t}$
$\ln \left[\frac{M-M_{e}}{M_{o}-M_{e}}\right]=-k t$

$$
\ln \left[\frac{M-M_{e}}{M_{o}-M_{e}}\right]=-k t
$$

Nilai $\frac{M-M_{e}}{M_{o}-M_{e}}$ disebut sebagai MR. M (Moisture) merupakan kadar air bahan selama proses pengeringan $t$ jam, Mo merupakan kadar air awal manisan pepaya dan Me adalah kadar air kesetimbangan manisan pepaya pada saat proses pengeringan.

Setelah memperoleh nilai konstanta laju pengeringan $k$ observasi kemudian akan ditentukan nilai konstanta laju pengeringan $k$ prediksi. Untuk mengetahui model terbaik digunakan koefisien determinasi $R^{2}$ dan Root Mean Square Error (RMSE) sebagai kriteria penilaian. Nilai $R^{2}$ digunakan sebagai kriteria pembanding untuk menentukan ketepatan model. Nilai RMSE merupakan deviasi antara nilai prediksi dari model dengan nilai hasil percobaan (Fithriani, Assadad, \& Arifin, 2017).

\section{HASIL DAN PEMBAHASAN}

\section{Temperatur}

Salah satu faktor penting dalam pengeringan adalah temperatur. Untuk dapat menguapkan air di dalam bahan maka digunakan suhu yang relatif tinggi. Peningkatan suhu akan mempengaruhi dan menentukan laju penguapan air bahan dalam proses pengeringan. Kecepatan transfer panas ke dalam bahan pangan dipengaruhi oleh perbedaan antara suhu media pemanas dengan bahan yang dikeringkan. Semakin besar perbedaan temperaturnya maka jumlah massa cairan yang diuapkan dari bahan akan lebih banyak dan lebih cepat. Kecepatan aliran udara juga mempengaruhi proses pengeringan dimana kecepatan udara yang lebih besar yang dikombinasikan dengan temperatur tinggi akan mempercepat proses pengeringan (M. Murad, Sabani, \& Putra, 2015).

Gambar 3 menunjukkan grafik hubungan antara waktu pengeringan dengan suhu di dalam ruang pengering. Seiring bertambahnya waktu pengeringan, suhu ruang pengering juga turut meningkat. Kecepatan udara juga memberikan pengaruh terhadap peningkatan suhu ruang pengering. Ekivalen dengan pertambahan waktu, penambahan kecepatan udara juga meningkatkan suhu ruang pengering. Dilihat pada 1 jam pertama hasil pengukuran suhu ruang pengering sebesar $41^{\circ} \mathrm{C}$ yang terus meningkat menjadi $64^{\circ} \mathrm{C}$ setelah 7 jam proses pengeringan untuk kecepatan aliran udara 3,43 m/detik, sedangkan pada kecepatan aliran udara 4,55 m/detik pada 1 jam pertama suhu terukurnya sebesar $34^{\circ} \mathrm{C}$ kemudian terus meningkat menjadi $66^{\circ} \mathrm{C}$ setelah 7 jam pengeringan. Tingkat kenaikan suhu menggunakan kecepatan aliran udara 4,55 m/detik masih lebih cepat daripada menggunakan kecepatan aliran udara $3.43 \mathrm{~m} /$ detik. Dapat dilihat pada Tabel 2, selain meningkatkan suhu udara menjadi lebih tinggi, kecepatan udara yang lebih besar dapat mencapai suhu udara ruang pengering minimum yang diinginkan 1 jam lebih cepat. Pada kecepatan aliran udara $4,55 \mathrm{~m} /$ detik suhu ruangan mencapai $60^{\circ} \mathrm{C}$ pada jam ke 2 sedangkan untuk kecepatan aliran udara $3.43 \mathrm{~m} /$ detik mencapainya pada jam ke-3. Namun secara umum, dapat disimpulkan bahwa terdapat hubungan yang berbanding lurus antara kecepatan aliran udara dengan suhu pada ruang pengering.

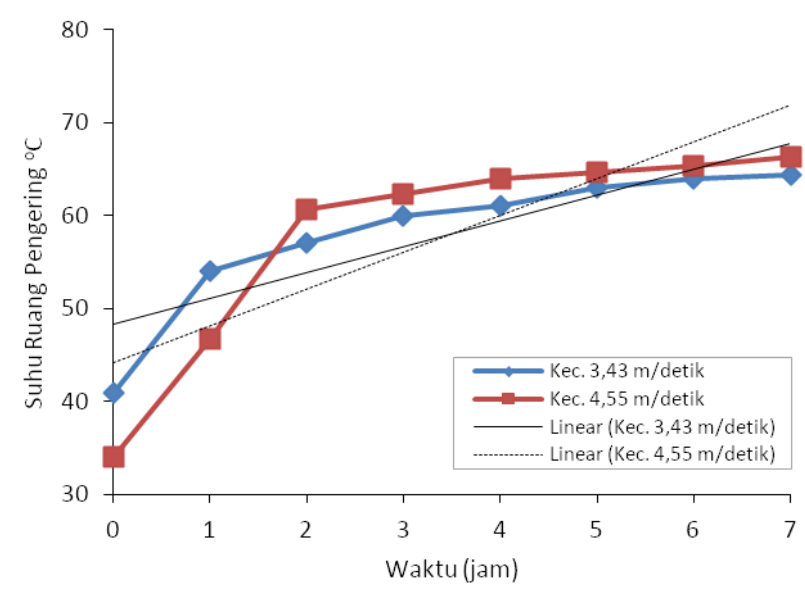

Gambar 3. Hubungan Waktu Pengeringan (Jam) versus Suhu Ruang Pengering $\left({ }^{\circ} \mathrm{C}\right)$ selama 7 jam waktu pengeringan

\section{Kelembaban Relatif}

Kemampuan udara untuk menyerap air mengindikasikan kelembaban relatif udara pengeringan. Di dalam ruang pengering, massa air dalam bahan secara perlahan dipanaskan dan diuapkan oleh udara panas. Uap air tidak langsung keluar dari ruang pengering akan tetapi menjenuhkan udara di sekitar bahan. Perbedaan tekanan uap antara permukaan bahan dan lingkungan menyebabkan kelembaban berkurang. Dengan $\mathrm{RH}$ udara pengeringan yang semakin rendah, maka semakin besar kemampuannya dalam menyerap uap air dan akan berlaku sebaliknya (Murad Murad, Sabani, Kurniawan, Muttalib, \& Khalil, 2019; Tunde-Akintunde, 2011).

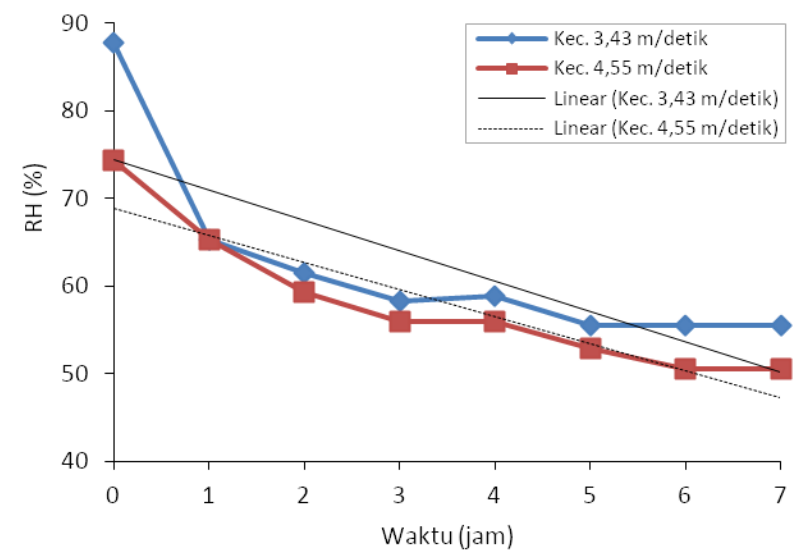

Gambar 4. Hubungan Antara Waktu Pengeringan (Jam) versus $\mathrm{RH}$ Ruang Pengering (\%) selama 7 jam waktu pengeringan 
Hubungan antara waktu pengeringan dan kelembaban udara $(\mathrm{RH})$ di dalam ruang pengering ditunjukkan pada Gambar 4. Seiring bertambahnya waktu pengeringan yang disertai peningkatan suhu di dalam ruang pengering maka $\mathrm{RH}$ juga semakin menurun. Penurunan nilai $\mathrm{RH}$ ini juga dipengaruhi oleh kecepatan aliran udara. Kecepatan aliran udara 4,55 m/detik menyebabkan $\mathrm{RH}$ turun lebih cepat dan lebih rendah dibandingkan dengan kecepatan aliran udara $3.43 \mathrm{~m} /$ detik. Dapat dilihat $\mathrm{RH} \approx 55 \%$ telah dicapai pada jam ke 3 untuk kecepatan aliran udara 4,55 m/detik dan pada jam ke-7 mencapai $\mathrm{RH}$ terendah $\approx 50 \%$. Sementara untuk kondisi $\mathrm{RH} \approx 55 \%$ pada kecepatan aliran udara 3.43 $\mathrm{m} /$ detik baru tercapai pada jam ke 5 dan merupakan $\mathrm{RH}$ terendahnya. Dengan demikian dapat disimpulkan bahwa kecepatan aliran udara yang lebih besar dapat lebih efektif dalam menyerap uap air bahan. Kondisi ini sesuai dengan pendapat yang menyatakan bahwa kecepatan udara yang tinggi akan meningkatkan kemampuan alat pengering dalam menampung dan membawa uap air yang dihasilkan oleh bahan (Syahrul, Romdhani, \& Mirmanto, 2016; TundeAkintunde, 2011).

\section{Kadar Air}

Tinggi-rendahnya suhu di dalam ruang pengering akan sangat mempengaruhi perubahan kadar air bahan. Perubahan suhu yang tinggi akan mengakibatkan semakin besarnya penguapan kadar air yang mengindikasikan terjadinya penurunan kadar air. Seiring bertambahnya waktu pengeringan suhu akan terus meningkat dan diikuti oleh penurunan kadar air (Murad Murad et al., 2019). Gambar 5 menunjukkan hubungan antara lamanya waktu pengeringan dengan penurunan kadar air:

Secara grafis hubungan antara waktu pengeringan versus kadar air bahan ditunjukkan pada Gambar 5 . Bertambahnya kecepatan aliran udara inlet disertai dengan semakin lamanya proses pengeringan maka akan menurunkan kadar air bahan. Pada jam ke 0 jumlah kadar air awal, secara berturut-turut, adalah 90,42 \% dan 94,00\% untuk kecepatan aliran udara 3,43 dan 4,55 m/detik. Setelah 7 jam kadar air bahan turun menjadi $24,19 \%$ dan $22,43 \%$ untuk masing-masing kecepatan aliran udara. Selain waktu pengeringan, faktor lain yang dapat mempengaruhi penurunan kadar air bahan adalah kecepatan aliran udara. Kecepatan udara yang besar dapat mempercepat penurunan kadar air bahan dengan jumlah yang lebih sedikit.

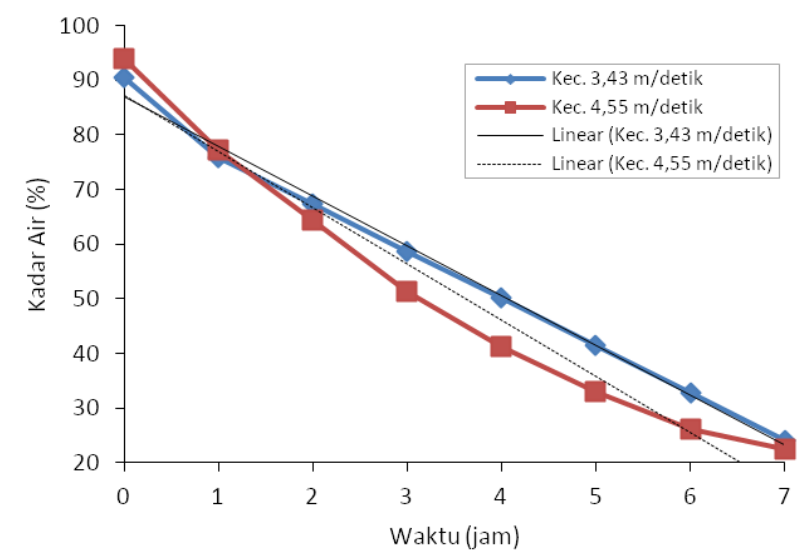

Gambar 5. Hubungan Waktu Pengeringan (Jam) versus Penurunan Kadar Air (\%) basis kering selama 7 jam waktu pengeringan

\section{Konstanta Laju Pengeringan Observasi}

Persamaan (3) yang menyatakan In MR versus waktu digunakan untuk menganalisis konstanta laju pengeringan manisan pepaya. Hasil analisis ditunjukkan dalam grafik hubungan In MR terhadap waktu pada Gambar 6 . Konstanta laju pengeringan ( $\mathrm{k}$ ) mengindikasikan jumlah uap air yang setiap menitnya dipindahkan pada proses pengeringan (Tunde-Akintunde, 2011). Nilai slope pada Gambar 6 menunjukkan besarnya konstanta laju pengeringan.

Indikator cepat lambatnya suatu proses pengeringan yang berlangsung pada suatu bahan dapat menggunakan Konstanta laju pengeringan ( $\mathrm{k}$ ). Besar nilai $k$ berbanding lurus dengan harga koefisien difusi suatu bahan yang dikeringkan (Erbay \& Icier, 2010).

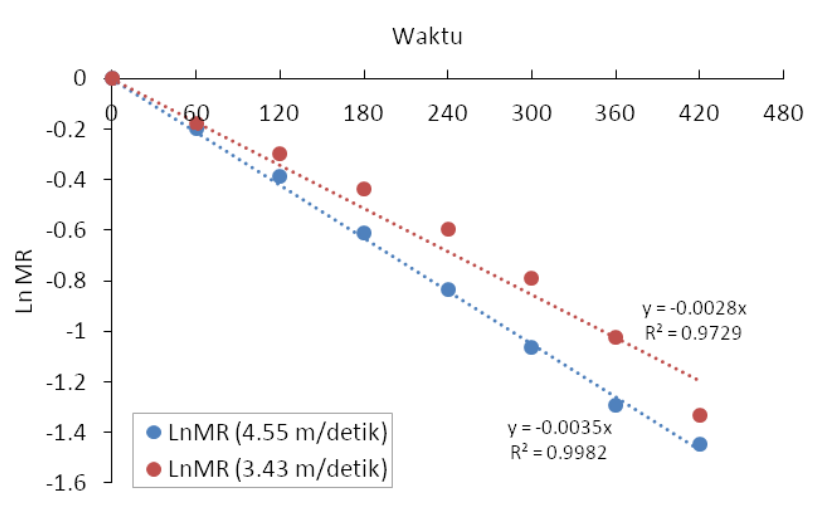

Gambar 6. Hubungan LnMR versus waktu pada kecepatan aliran udara $3.43 \mathrm{~m} /$ detik dan $4,55 \mathrm{~m} /$ detik.

Nilai $k$ juga dapat digunakan untuk memprediksi lamanya waktu yang dibutuhkan untuk mencapai kadar air tertentu. Pada Gambar 6 dapat dilihat bahwa nilai $k$ adalah negatif yang diperoleh dari slope pada grafik negatif. Semakin lama waktu pengeringan maka kadar air yang dihasilkan akan semakin kecil. Nilai MR berbanding lurus dengan waktu pengeringan (Akoy, 2014). Slope akan dihasilkan lebih besar jika panas yang diberikan lebih tinggi. Tabel 2 menunjukkan nilai $k$ pada variasi kecepatan aliran udara pengeringan manisan pepaya. Secara berturut-turut nilai $k$ untuk masing-masing kecepatan aliran udara 3.43 $\mathrm{m} /$ detik dan $4,55 \mathrm{~m} /$ detik adalah 0.0028 dan 0.0035 . Untuk kecepatan aliran udara yang lebih besar memiliki nilai $k$ yang lebih besar. Atau dapat dikatakan bahwa semakin besar kecepatan aliran udara maka konstanta laju pengeringan (k) juga semakin besar. Kondisi ini sesuai dengan pernyataan bahwa laju pengeringan dipengaruhi oleh beberapa faktor salah satu diantaranya adalah kecepatan aliran udara (Ummah et al., 2016). Karena kecepatan aliran udara memiliki pengaruh terhadap peningkatan suhu ruang pengering (Ummah et al., 2016).

Tabel 2. Konstanta laju pengeringan $k$ pada kecepatan aliran udara 3,43 m/detik dan 4,55 m/detik.

\begin{tabular}{ccc}
\hline Konstanta & $\begin{array}{c}\text { Kecepatan Aliran } \\
\text { Udara 3,43m/detik }\end{array}$ & $\begin{array}{c}\text { Kecepatan Aliran } \\
\text { Udara 4,55m/detik }\end{array}$ \\
\hline$k$ & 0,0028 & 0,0035 \\
\hline
\end{tabular}

Konstanta laju pengeringan $(k)$ merupakan sebuah indikator cepat atau lambatnya proses pengeringan suatu bahan yang dikeringkan. Nilai $(k)$ bergantung pada besar nilai koefisien difusi bahan. Semakin besar nilai koefisien difusi bahan maka semakin tinggi pula nilai $(\mathrm{k})$, begitupun sebaliknya. Selain koefisien difusi, cepat atau lambatnya 
proses pengeringan juga sangat tergantung pada energi (suhu) dan laju aliran massa udara pengering yang diberikan kepada sistem pengeringan tersebut (Kade Suriadi \& Ricki Murti, 2012; Ummah et al., 2016).

\section{Konstanta Laju Pengeringan Prediksi}

Pada penelitian ini nilai $k$ observasi digunakan untuk memprediksi nilai $k$ sebagai fungsi waktu untuk setiap kecepatan aliran udara. Dengan analisis SPSS versi 25 diperoleh nilai k-prediksi sebagai berikut:

$k-$ pred $_{4,55 m / \text { detik }}=0.015-0.004 t$
$k-$ pred $_{3.43 m / \text { detik }}=0.051-0.003 t$

Dengan memasukkan nilai $\mathrm{t}$ sama dengan $0-7$ jam dengan interval masing-masing 1 jam (60 menit) diperoleh tabel $k$ observasi dan $k$ prediksi seperti ditunjukkan pada Tabel 3.

Tabel3. Hasil pengujian $k$ observasi dan $k$ prediksi manisan pepaya

\begin{tabular}{cclll}
\hline $\begin{array}{c}\text { Kecepatan } \\
\text { Aliran Udara } \\
\text { (m/detik) }\end{array}$ & $\begin{array}{c}\text { Waktu } \\
\mathrm{t} \text { (jam) }\end{array}$ & $\begin{array}{c}k \\
\text { Observasi }\end{array}$ & $\begin{array}{c}k \\
\text { Prediksi }\end{array}$ & RMSE \\
\hline & 0 & $-4 \mathrm{E}-05$ & 0,015 & \\
& 1 & $-0,1983$ & $-0,225$ & \\
4,55 m/detik & 2 & $-0,3845$ & $-0,465$ & \\
& 3 & $-0,6119$ & $-0,705$ & 0.125 \\
& 4 & $-0,835$ & $-0,945$ & \\
& 5 & $-1,0606$ & $-1,185$ & \\
& 6 & $-1,2933$ & $-1,425$ & \\
& 7 & $-1,4464$ & $-1,665$ & \\
& 0 & $-5 \mathrm{E}-05$ & 0,051 & \\
& 1 & $-0,1772$ & $-0,129$ & \\
& 2 & $-0,2989$ & $-0,309$ & \\
& 3 & $-0,4373$ & $-0,489$ & 0.065 \\
& 4 & $-0,5975$ & $-0,669$ & \\
& 5 & $-0,7877$ & $-0,849$ & \\
& 6 & $-1,0231$ & $-1,029$ & \\
& 7 & $-1,333$ & $-1,209$ & \\
\hline
\end{tabular}

Persamaan (4) dan persamaan (5) dapat digunakan untuk memprediksi konstanta laju pengeringan $(k)$ manisan pepaya. Konstanta laju pengeringan manisan pepaya hasil observasi dibandingkan dengan hasil perhitungan kemudian diplotkan dan disajikan pada Gambar 7. Dapat dilihat hubungan antara $k$ observasi dengan $k$ prediksi untuk setiap perlakuan kecepatan aliran udara. Kedua kondisi dapat menggambarkan laju pengeringan observasi yang dapat diterima karena nilai $R^{2}$ keduanya lebih besar dari $90 \%$. Namun jika dibandingkan dari nilai RMSEnya, maka dapat dikatakan bahwa kecepatan aliran udara 3.43 $\mathrm{m} /$ detik memiliki nilai $k$ prediksi yang lebih dekat dengan nilai $k$ observasi.

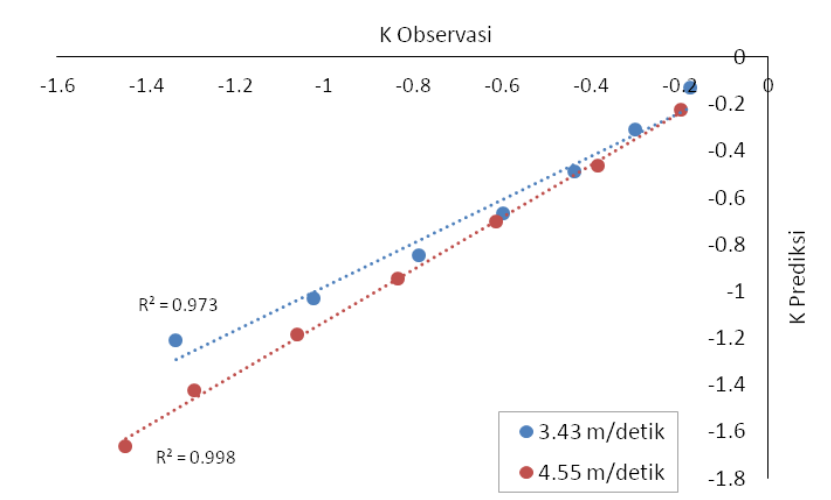

Gambar 7. Hubungan k observasi dan k prediksi untuk pengeringan manisan pepaya

\section{KESIMPULAN}

Penggunaan kecepatan aliran udara $3.43 \mathrm{~m} /$ detik atau $4,55 \mathrm{~m} /$ detik dalam proses pengeringan manisan pepaya menggunakan alat pengering tipe rak tidak memberikan perbedaan yang signifikan. Dllihat dari nilai laju pengeringan prediksi ( $k$ prediksi) dan observasi $(k$ observasi) masing-masing nilai $R^{2}$ keduanya sama-sama di atas $90 \%$. Meskipun demikian, penggunaan laju aliran udara yang lebih besar terbukti dapat mempercepat proses pengeringan.

\section{UCAPAN TERIMAKASIH}

Kami sampaikan ucapan terima kasih kepada semua pihak di Fatepa - Universitas Mataram yang telah mendukung terlaksananya penelitian ini.

\section{DAFTAR PUSTAKA}

Akoy, E. O. M. (2014). Experimental characterization and modeling of thin-layer drying of mango slices. International Food Research Journal, 21(5), 19111917.

Attri, S., Dhiman, A. K., Sharma, R., \& Kaushal, M. (2016). Standardization of Pre-treatments for the Development of Intermediate Moisture Food Products from Papaya ( Carica papaya L.) . International Journal of Food and Fermentation Technology, 6(1), 143. https://doi.org/10.5958/22779396.2016.00037.4

El-Beltagy, A., Gamea, G. R., \& Essa, A. H. A. (2007). Solar drying characteristics of strawberry. Journal of Food Engineering, 78(2), 456-464. https://doi.org/10.1016/j.jfoodeng.2005.10.015

Erbay, Z., \& Icier, F. (2010). A review of thin layer drying of foods: Theory, modeling, and experimental results. Critical Reviews in Food Science and Nutrition, 50(5), https://doi.org/10.1080/10408390802437063

Fithriani, D., Assadad, L., \& Arifin, Z. (2017). Karakteristik dan Model Matematika Kurva Pengeringan Rumput Laut Eucheuma cottonii. Jurnal Pascapanen Dan Bioteknologi Kelautan Dan Perikanan, 11(2), 159. https://doi.org/10.15578/jpbkp.v11i2.290

Kade Suriadi, I. G. A., \& Ricki Murti, M. (2012). Kesetimbangan Energi Termal Dan Efisiensi Transient Pengering Aliran Alami Memanfaatkan Kombinasi Dua Energi. Jurnal Teknik Industri, 12(1), 
34. https://doi.org/10.22219/jtiumm.vol12.no1.34-40

Kannaujiya, A., Bunkar, D. S., Rai, D. C., \& Singh, U. P. (2018). Process optimization for the development of papaya candy and its shelf-life evaluation. The Pharma Innovation Journal, 7(4), 80-85.

Khan, M. I. H., Rahman, M. M., \& Karim, M. A. (2020). Recent advances in micro-level experimental investigation in food drying technology. Drying Technology, 38(5-6), 557-576. https://doi.org/10.1080/07373937.2019.1657145

Murad, M., Sabani, R., \& Putra, G. (2015). Pengeringan Biji Kemiri Pada Alat Pengering Tipe Batch Model Tungku Berbasis Bahan Bakar Cangkang Kemiri. Jurnal Ilmiah Rekayasa Pertanian Dan Biosistem, 3(1), $122-127$.

Murad, Murad, Sabani, R., Kurniawan, H., Muttalib, S. A., \& Khalil, F. I. (2019). Karakteristik Pengeringan Sawut Mocaf Menggunakan Alat Pengering Tenaga Surya Tipe Greenhouse. Jurnal IImiah Rekayasa Pertanian Dan Biosistem, 7(1), 105-115. https://doi.org/10.29303/jrpb.v7i1.103

Onwude, D. I., Hashim, N., Janius, R. B., Nawi, N. M., \& Abdan, K. (2016). Modeling the Thin-Layer Drying of Fruits and Vegetables: A Review. Comprehensive Reviews in Food Science and Food Safety, 15(3), 599-618. https://doi.org/10.1111/1541-4337.12196

Shomali, A., \& Abbasi Souraki, B. (2019). Experimental investigation and mathematical modeling of drying of green tea leaves in a multi-tray cabinet dryer. Heat and Mass Transfer/Waerme- Und Stoffuebertragung, 55(12), 3645-3659. https://doi.org/10.1007/s00231019-02662-6

Syahrul, S., Romdhani, R., \& Mirmanto, M. (2016). Pengaruh variasi kecepatan udara dan massa bahan terhadap waktu pengeringan jagung pada alat fluidized bed. Dinamika Teknik Mesin, 6(2), 119126. https://doi.org/10.29303/d.v6i2.15

Taufiq, M. (2004). Pengaruh Temperatur Terhadap Laju Pengeringan Jagung pada Pengering Konvensional dan Fluidized Bed. Universitas Sebelas Maret.

Tunde-Akintunde, T. Y. (2011). Mathematical modeling of sun and solar drying of chilli pepper. Renewable Energy, 36(8), 2139-2145. https://doi.org/10.1016/j.renene.2011.01.017

Ummah, N., Purwanto, Y. A., \& Suryani, A. (2016). Penentuan Konstanta Laju Pengeringan Bawang Merah ( Allium. Warta IHP/Journal of Agro-Based Industry, 33(2), 49-56.

Vega-Gálvez, A., Ah-Hen, K., Chacana, M., Vergara, J., Martínez-Monzó, J., García-Segovia, P., ... Di Scala, K. (2012). Effect of temperature and air velocity on drying kinetics, antioxidant capacity, total phenolic content, colour, texture and microstructure of apple (var. Granny Smith) slices. Food Chemistry, 132(1), 51-59.

https://doi.org/10.1016/j.foodchem.2011.10.029

Yogiraj, V., Goyal, P. K., Chauhan, C. S., Goyal, A., \& Vyas, B. (2014). Carica papaya Linn: an overview. International Journal of Herbal Medicine, 2(5 Part A), $1-8$.

Zhang, R., \& Long, J. (2017). Study on Drying Uniformity of Static Small-sized Drying Box for Fruits and Vegetables. Procedia Engineering, 205, 2615-2622. https://doi.org/10.1016/j.proeng.2017.10.201 